\title{
Effects of corticotrophin-releasing hormone, vasopressin and insulin-like growth factor-I on proliferation of and adrenocorticotrophic hormone secretion by canine corticotrophic adenoma cells in vitro
}

\author{
Petra A van Wijk, Ad Rijnberk, Ronald JM Croughs ${ }^{1}$, Björn P Meij and Jan A Mol \\ Department of Clinical Sciences of Companion Animals, Faculty of Veterinary Medicine, Utrecht University, Utrecht, The Netherlands, and \\ ${ }^{1}$ Department of Endocrinology, Utrecht University Hospital, Utrecht, The Netherlands \\ (Correspondence should be addressed to JA Mol, Department of Clinical Sciences of Companion Animals, Faculty of Veterinary Medicine \\ Utrecht University, PO Box 80.154, 3508 TD Utrecht, The Netherlands)
}

\begin{abstract}
Extrinsic factors such as hypothalamic hormones or intrapituitary growth factors may stimulate clonal expansion of a genomically altered cell and therefore play a role in pituitary tumorigenesis. Here we report on the effects of the hypophysiotrophic hormones corticotrophin-releasing hormone (CRH) and vasopressin (AVP) and the intrapituitary growth factor insulin-like growth factor-I (IGF-I) on the proliferation of, as measured by the bromodeoxyuridine labelling index, and ACTH secretion by normal canine pituitary cells and corticotrophic adenoma cells of dogs with pituitary-dependent hyperadrenocorticism. The sensitivity to inhibition by cortisol was analysed under various conditions.

Under basal conditions, no significant differences were found in the bromodeoxyuridine labelling indices between control cells and tumour cells. CRH, AVP, IGF-I and cortisol had no effect on the proliferation of canine pituitary cells or canine corticotrophic adenoma cells. In contrast with normal pituitary cells, the proliferation of corticotrophic adenoma cells was stimulated by fetal calf serum (FCS). This FCS-induced proliferation was not inhibited by cortisol.

The CRH-induced ACTH secretion by corticotrophic adenoma cells was significantly $(P<0.05)$ lower than that by normal pituitary cells after $4 \mathrm{~h}$ incubation with CRH. Incubation with cortisol for $24 \mathrm{~h}$ resulted in reduced ACTH secretion under basal and AVP- or IGF-I-stimulated conditions. The relative inhibition was, however, significantly $(P<0.05)$ lower in ACTH-producing tumour cells than in normal pituitary cells. Cortisol did not inhibit the CRH-induced ACTH secretion in normal pituitary cells after $24 \mathrm{~h}$.

In conclusion, canine corticotrophic adenomas are less sensitive to stimulation by CRH and less sensitive to inhibition by glucocorticoids. These tumours have an aberrant sensitivity to a growthpromoting factor present in FCS. This factor may have an important role in the growth promotion of canine corticotrophic tumours.
\end{abstract}

European Journal of Endocrinology 138 309-315

\section{Introduction}

Pituitary adenomas are currently believed to be monoclonal in origin, indicating that they arise from a genetically transformed cell. The promotion of this transformed cell can be caused by intrinsic mutations and/or by extrinsic factors such as hypothalamic hormones or intrapituitary growth factors.

Activating mutations in the $\alpha$-subunit of the Gs protein have been found in about $40 \%$ of the growth hormone-secreting adenomas $(1,2)$, in $10 \%$ of nonfunctioning pituitary adenomas ( 3 ) and in $6 \%$ of corticotrophic adenomas (4). In a small number of pituitary carcinomas, mutations in the retinoblastoma (5), H-ras $(6,7)$ and protein kinase $C(8)$ genes have been reported.
These changes have been found in relatively few tumours $(9,10)$ and there is as yet no evidence that other cellular oncogenes or tumour suppressor genes play a role in the development of pituitary adenomas.

The clonal expansion may require the action of hypothalamic hormones and/or intrapituitary growth factors. Administration of corticotrophin-releasing hormone $(\mathrm{CRH})$ and vasopressin $(\mathrm{AVP})$ to rats increases the number of corticotrophic cells (11-14). Growth hormone-releasing hormone transgenic mice develop somatotrophic adenomas (15) and gonadotrophin-releasing hormone stimulates gonadotrophic cell proliferation in rats (16). Moreover, the pituitary gland contains several growth factors $(17,18)$, such as insulin-like growth factor (IGF-I/II) (19), epidermal 
growth factor $(20,21)$, basic fibroblast growth factor $(22-24)$ and transforming growth factor- $\alpha / \beta$ (18). These growth factors may affect the function and proliferation of pituitary cells through autocrine or paracrine actions in the pituitary (25). We have shown stimulating effects of $\mathrm{CRH}$, AVP, basic fibroblast growth factor, epidermal growth factor and IGF-I on the proliferation of a murine corticotrophic tumour cell line (AtT20) (26). The growth factor-induced proliferation of AtT20 cells appeared to be less sensitive to inhibition by glucocorticoids than the proliferation induced by hypothalamic hormones, and the IGF-I-induced proliferation was the least sensitive to inhibition by cortisol (26).

Here we report on the effects of CRH, AVP and IGF-I on the proliferation of and adrenocorticotrophin (ACTH) secretion by normal pituitary cells and corticotrophic adenoma cells of dogs with pituitary-dependent hyperadrenocorticism (PDH), which is generally regarded to be a valuable model for pathogenetic studies (27). The sensitivity to inhibition by cortisol was analysed under various conditions.

\section{Materials and methods}

\section{Tissue culture}

Pituitaries were collected by trans-sphenoidal hypophysectomy in 12 clinically healthy dogs and 8 dogs with PDH. Diagnosis of PDH was based upon measurements of corticoid/creatinine ratios in urine before and after dexamethasone administration (28), measurements of plasma ACTH concentration (29) and computed tomography of the pituitary gland (30). Total hypophysectomy was performed by the trans-sphenoidal approach described by Markowitz et al. (31), with slight modifications. Anaesthesia was induced by the administration of $0.015 \mathrm{mg}$ fentanyl $/ \mathrm{kg}, 0.75 \mathrm{mg}$ droperidol $/ \mathrm{kg}$ (Thalamonal; Janssen Pharmaceutica BV, Tilburg, The Netherlands) and $0.05 \mathrm{mg}$ atropine/kg (Atropini Sulfas; Pharmachemie BV, Haarlem, The Netherlands), followed by the i.v. administration of $5 \mathrm{mg}$ propofol $/ \mathrm{kg}$ (Diprivan; Zeneca BV, Ridderkerk, The Netherlands). The trachea was intubated and anaesthesia was then maintained by inhalation of a mixture of isoflurane (Forene; Abbott BV, Maarssen, The Netherlands), $\mathrm{NO}_{2}$ and oxygen in a semi-closed system. Analgesia was provided by sufentanil (Sufenta; Janssen Pharmaceutica BV) administered by an i.v. pump at a rate of $2.5 \mu \mathrm{g} / \mathrm{kg}$ per h.

Immediately after its removal, pituitary tissue was placed in Hanks balanced salt solution (HBSS) (JRH Biosciences, Lenexa, KS, USA) supplemented with $2 \mathrm{mM}$ L-glutamine (Biochrom KG, Berlin, Germany), $10 \mathrm{U}$ penicillin/ml (Kombivet, Etten-Leur, The Netherlands) and $10 \mathrm{mg}$ streptomycin $/ \mathrm{ml}$ (Alfasan, Woerden, The Netherlands) at $4{ }^{\circ} \mathrm{C}$. The pituitary fragments were washed three times with HBSS, minced and incubated in dispase $(2.4 \mathrm{U} / \mathrm{ml}$ HBSS) (Boehringer, Mannheim,
Germany) for $90-120 \mathrm{~min}$ at $37^{\circ} \mathrm{C}$. After two washes with HBSS, the cells were mechanically dispersed with a tissue grinder. The dispersed cells were plated on to 24well plates (Greiner, Alphen a/d Rijn, The Netherlands) and grown at $37{ }^{\circ} \mathrm{C}$ in a humidified atmosphere of $5 \%$ $\mathrm{CO}_{2} / 95 \%$ air. The culture medium consisted of minimum essential medium supplemented with D-valine (Life Technologies, Breda, The Netherlands), 10\% fetal calf serum (FCS) (Sebak, Aidenbach, Germany), $10 \mathrm{U}$ penicillin $/ \mathrm{ml}$ and $10 \mathrm{mg}$ streptomycin $/ \mathrm{ml}$.

\section{Proliferation studies}

During the proliferation studies, the FCS in the medium described above was replaced by growth factorinactivated FCS (SH-FCS) supplemented with $0.2 \%$ (w/v) BSA (Sigma, St Louis, MO, USA), $30 \mathrm{nM} \mathrm{Na}_{2} \mathrm{SeO}_{3}$ (Sigma) and $10 \mu \mathrm{g}$ transferrin/ml (Sigma) (32).

The proliferation studies were conducted with tumour material from seven dogs with PDH and six pituitaries from clinically healthy dogs. The cells were plated on to poly-D-lysine-coated coverslips (Nunc Inc, Naperville, IL, USA) at a density of $2 \times 10^{4}$ cells per well and were grown for 2 days in medium with 10\% FCS. The cells were washed and incubated with SH-FCS medium supplemented with $10 \mathrm{nM} \mathrm{CRH}$ (Peninsula Laboratories, St Helens, Merseyside,UK), $100 \mathrm{nM}$ AVP (Sigma), $100 \mathrm{ng}$ IGF-I/ml (Boehringer) or medium with $10 \%$ FCS, with and without $100 \mathrm{nM}$ cortisol (Sigma) (three wells per incubation) at day 0. On day 4 of incubation, the medium was changed. On day 7 of incubation, the cells were incubated with bromodeoxyuridine $(\mathrm{BrdU} ; 20 \mathrm{nmol} / \mathrm{ml}$ per well; following the protocol described in the 5-bromo-2-deoxyuridine labelling and detection kit II from Boehringer) for $1 \mathrm{~h}$. The cells were fixed with ethanol and incubated with mouse anti-BrdU. After incubation with anti-mouse IgG-alkaline phosphatase followed by the substrate reaction, bound anti-BrdU was visualized by light microscopy.

\section{Secretion studies}

The secretion studies were conducted with tumour material from eight dogs with $\mathrm{PDH}$ and 12 pituitaries obtained from clinically healthy dogs. Cells were plated on to 24-well plates at a density of $10^{5}$ cells per well in medium with FCS, as described above. After 2 days, the cells were washed and incubated with medium in which FCS was replaced by $0.2 \%(\mathrm{w} / \mathrm{v})$ BSA and supplemented with $10 \mathrm{nM}$ CRH, $100 \mathrm{nM}$ AVP or $100 \mathrm{ng}$ IGF-I/ml, with and without $100 \mathrm{nM}$ cortisol. After 4 and $24 \mathrm{~h}$, the medium was removed from the cells and stored at $-20^{\circ} \mathrm{C}$. The ACTH content of the medium was measured by RIA without extraction, by the procedure of Arts et al. (33). Antiserum was obtained from IgG Corporation (Nashville, TN, USA). The tracer was purchased from International CIS (St Quentin-Yvelines, 

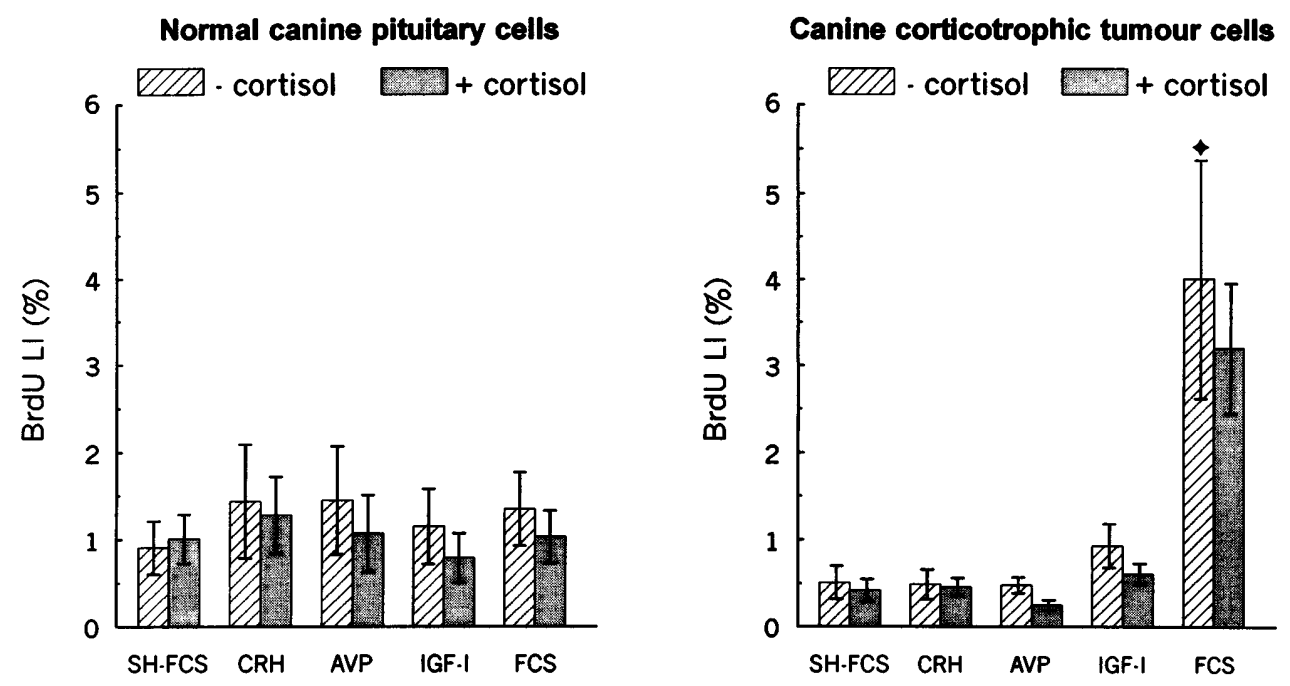

Figure $1 \mathrm{BrdU}$ labelling indices (BrdU LI) of normal canine pituitary cells and canine corticotrophic tumour cells after 7 days of incubation with CRH (10 nM), AVP (100 nM), IGF-I $(100 \mathrm{ng} / \mathrm{ml})$ or $10 \%$ FCS with or without $100 \mathrm{nM}$ cortisol. Data are expressed as mean \pm S.E.M. $\checkmark$, BrdU LI is significantly higher than in SH-FCS medium without cortisol. $P<0.05$ was considered significant.

France), and the standard was obtained from the National Institutes of Health (Bethesda, MD, USA). The detection limit was $10 \mathrm{ng} / \mathrm{l}$. Interassay variation was $12 \%$.

\section{Calculations and statistics}

To determine the BrdU labelling index, at least 250 cells/ coverslip (three coverslips/incubation) were counted. The BrdU labelling index was calculated as the percentage of the total number of nuclei counted that were BrdU labelled. The results are presented as mean \pm s.E.M.

In the secretion studies, the average ACTH concentration per incubation (three wells/incubation) was determined and expressed as a percentage of ACTH secretion into the control medium. The percentage change in ACTH secretion induced by cortisol was calculated per incubation. The results are presented as mean \pm s.E.M.

Differences between the incubations were tested, using the SPSS statistical software package, with the Friedman test followed by the Wilcoxon signed ranks test for differences within groups. Differences between groups were calculated using the Mann-Whitney test. $P<0.05$ was considered significant.

\section{Results}

In the normal pituitary, the corticotrophic cells constitute about $10 \%$ of the adenohypophyseal cells (34), whereas in corticotrophic adenomas this percentage is far exceeded. The absolute amount of ACTH production differs between primary cultures of adenoma and normal pituitary cells. These differences hamper the comparison of the absolute effects of various factors on the proliferation of and ACTH secretion by corticotrophic cells. Therefore, in the proliferation studies, values are expressed as percentage BrdU-positive cells and in the secretion studies values are expressed as percentage of the control (the absolute values are set at 100\%).

\section{Proliferation studies}

After incubation in the growth-factor depleted medium (SH-FCS medium), the differences in BrdU labelling index between the control cells $(0.9 \pm 0.3 \% ; n=6)$ and the tumour cells $(0.5 \pm 0.2 \% ; n=7)$ were not significant. The hypophysiotrophic hormones CRH and AVP, the intrapituitary growth factor IGF-I, and cortisol had no effect on the proliferation of canine pituitary cells or canine corticotrophic adenoma cells (Fig. 1). In the tumour cells, incubation with FCS $(4.0 \pm 1.4 \%)$ resulted in significantly $(P<0.05)$ higher BrdU labelling index compared with incubation with SH-FCS medium, whereas in the control cells, the BrdU labelling index after incubation with FCS $(1.3 \pm 0.4 \%)$ was not different from that after incubation with SH-FCS medium. FCSinduced proliferation of the corticotrophic adenoma cells was not inhibited by cortisol $(3.2 \pm 0.8 \%)$.

\section{Secretion studies}

Basal ACTH secretion by normal pituitary cells $(n=12)$ amounted to $746 \pm 156$ and $2800 \pm 413 \mathrm{ng} / \mathrm{l}$ after 4 and $24 \mathrm{~h}$ of incubation respectively. ACTH secretion increased significantly $(P<0.05)$ after 4 and $24 \mathrm{~h}$ of incubation with $\mathrm{CRH}(316.8 \pm 39.8 \%$ and $236.2 \pm$ $22.1 \%)$, AVP $(123.3 \pm 8.8 \%$ and $113.5 \pm 5.1 \%)$ and IGF-I $(136.4 \pm 13.2 \%$ and $137.2 \pm 13.8 \%)$ compared 
with ACTH secretion in the control medium $(100 \%)$. Cortisol significantly $(P<0.05)$ inhibited the ACTH secretion stimulated by CRH $(28.1 \pm 4.3 \%)$, AVP $(8.9 \pm$ $4.2 \%)$, and IGF-I $(10.0 \pm 2.0 \%)$ after $4 \mathrm{~h}$ of incubation. After $24 \mathrm{~h}$ of incubation, cortisol significantly $(P<0.05)$ inhibited basal ACTH secretion $(53.9 \pm 5.6 \%)$ and the ACTH secretion stimulated by AVP $(56.6 \pm 5.1 \%)$ and IGF-I (66.2 $\pm 3.3 \%)$, whereas the CRH-induced ACTH secretion was not significantly inhibited $(3.1 \pm 6.7 \%)$ (Figs 2a and $\mathrm{b}$ ).

The basal ACTH secretion by corticotrophic adenoma cells $(n=8)$ amounted to $2600 \pm 1377$ and $3028 \pm$ $1555 \mathrm{ng} / \mathrm{l}$ after 4 and $24 \mathrm{~h}$ incubation respectively. The ACTH secretion was significantly stimulated by $\mathrm{CRH}$ after $4 \mathrm{~h}(184.2 \pm 19.6 \%)$ and $24 \mathrm{~h}(309.7 \pm 44.1 \%)$ as well as by AVP $(142.7 \pm 14.0 \%)$ after $24 \mathrm{~h}$. The CRHinduced ACTH secretion was significantly $(P<0.05)$ inhibited by cortisol $(26.5 \pm 5.5 \%$ and $20.0 \pm 7.7 \%)$ after 4 and $24 \mathrm{~h}$ of incubation. Cortisol significantly $(P<0.05)$ inhibited basal ACTH secretion $(21.9 \pm$ $6.1 \%$ ) and the ACTH secretion stimulated by AVP $(24.1 \pm 9.7 \%)$ after $24 \mathrm{~h}$ of incubation. The ACTH secretion by corticotrophic adenoma cells was not stimulated by IGF-I after 4 and $24 \mathrm{~h}$ of incubation. During co-incubation with IGF-I, basal ACTH secretion was not inhibited by cortisol after 4 and $24 \mathrm{~h}$ (Figs 2c and d).

After $4 \mathrm{~h}$ of incubation, the CRH-induced ACTH secretion by canine corticotrophic tumour cells was significantly $(P<0.05)$ lower than that by normal canine pituitary cells.

During the $24 \mathrm{~h}$ incubations, the inhibition by cortisol of basal ACTH secretion and the inhibition by cortisol of the ACTH secretion during co-incubation

\section{Normal canine pituitary cells}

(a)

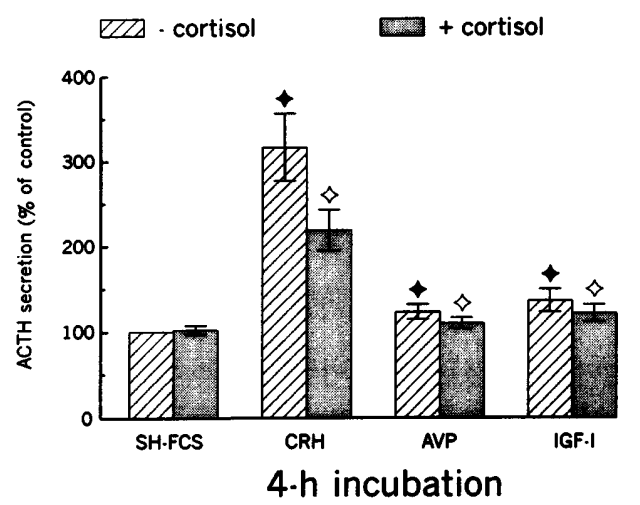

(b)

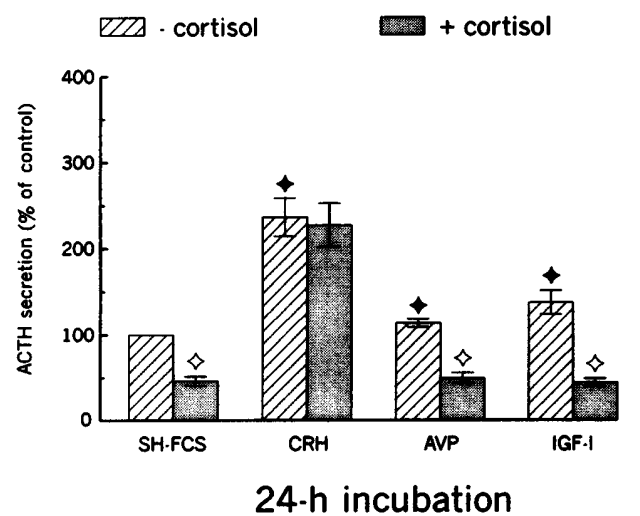

\section{Canine corticotrophic tumour cells}

(c)

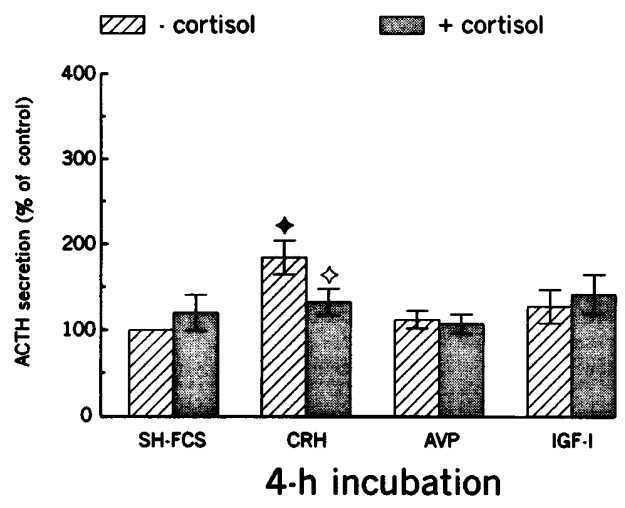

(d)

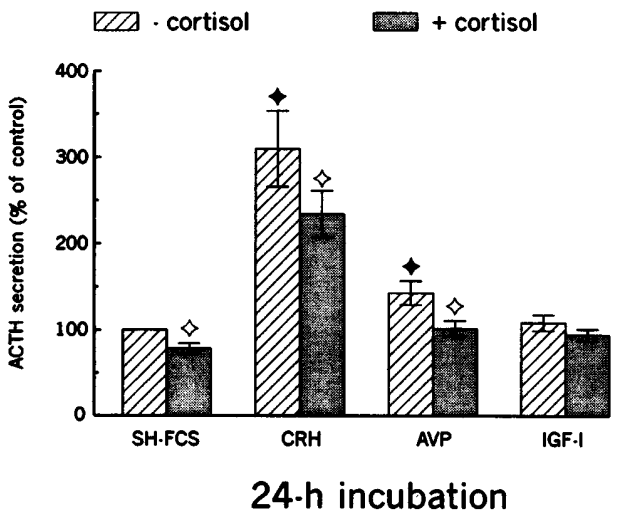

Figure 2 ACTH concentrations in media from normal canine pituitary cells ( $a$ and $b$ ) and canine corticotrophic tumour cells (c and d) after 4 and $24 \mathrm{~h}$ of incubation with CRH $(10 \mathrm{nM})$, AVP $(100 \mathrm{nM})$ or IGF-I $(100 \mathrm{ng} / \mathrm{ml})$ with or without $100 \mathrm{nM}$ cortisol. ACTH concentration is expressed as a percentage of that in the control medium. Data are expressed as mean \pm S.E.M. $\bullet$, Statistically different from the ACTH concentration in the control medium. $\diamond$, Significant inhibition by cortisol. $P<0.05$ was considered significant. 
with AVP and IGF-I were significantly $(P<0.05)$ lower in ACTH-producing tumour cells than in the same incubations with normal pituitary cells.

\section{Discussion}

Of the hypothalamic factors that regulate ACTH secretion from the anterior pituitary, CRH and AVP are the most potent stimulatory neurohormones (3537). After transformation of pituitary corticotropes into ACTH-producing adenomas, the responsiveness to $\mathrm{CRH}$ and AVP is altered and there is a decreased sensitivity to feedback by glucocorticoids. Apart from their effect on the release of ACTH, hypothalamic hormones and intrapituitary growth factors may facilitate clonal expansion of the genetically altered corticotrophic cell.

In the present study, the hypothalamic hormones CRH and AVP were found to have no stimulatory effects on the proliferation of normal canine pituitary cells nor on the proliferation of canine corticotrophic tumour cells. This indicates that hypophysiotrophic hormones do not play an important role in the promotion of ACTH-secreting corticotrophic adenomas in dogs with PDH (Cushing's disease). This is in concordance with results from earlier studies. In man and dog, it has been shown that the excessive ACTH secretion in Cushing's disease is not caused by persistent hyperstimulation of corticotropes by $\mathrm{CRH}(29,38)$, and canine ACTH-producing tumours have been shown to be relatively insensitive to stimulation by hypothalamic hormones in vitro (39).

The anterior pituitary gland consists of cells with a relatively low mitotic rate. The proliferative activity of canine hypophyseal cells in vivo is $0.05 \%$ (40), which is lower than the proliferation rate in vitro. We found FCS to have a stimulating effect on the proliferation of canine corticotrophic adenoma cells in vitro. This indicates that canine ACTH-producing pituitary tumour cells develop an aberrant sensitivity to growthpromoting stimulation by a factor present in FCS. It would be very interesting to find out what factor is responsible in order to know which signal-transduction pathway becomes activated in these (post-mitotic) cells. This factor, and therefore the signal-transduction pathway activated, may have a profound role in the clonal expansion of these tumours. From the results of this study, we conclude that the factor is not CRH, AVP or IGF-I. For preparation of the growth factor-depleted serum, FCS was treated with dithiothreitol and iodoacetamide, which destroys disulphide bridges, and dialysed for 3-4 days (molecular mass cut-off 6$8 \mathrm{kDa})$. Polypeptide growth factors require intact disulphide bridges for their activity (32). The unknown factor in FCS may therefore be a factor containing disulphide bridges, such as polypeptide growth factors, and/or be a factor with a molecular mass below 6$8 \mathrm{kDa}$. The idea that the unknown factor may be a growth factor is supported by results from our study with AtT20 cells. Proliferation of murine corticotrophic tumour cells (AtT20) induced by growth factors is, in comparison with hypothalamic neurohormones, relatively insensitive to inhibition by glucocorticoids (26). The FCS-induced proliferation of canine corticotrophic tumour cells is not sensitive to inhibition by glucocorticoids.

Because the amount of cells harvested was not sufficient to test a great variety of growth factors, we decided, on the basis of our study with AtT20 cells (26), to test CRH, AVP and IGF-I alone and in combination with cortisol. As none of these peptides mimic the FCSinduced proliferation, further investigations are needed to elucidate the stimulating factor present in FCS. Several candidate peptides can be put forward. Tilemans et al. (41) showed that the development of prolactin-, growth-hormone- and ACTH-containing cells in the anterior pituitary of the rat is modulated by luteinizing hormone-releasing hormone and that the action of this hormone is mediated by specific growth factors released from gonadotropes. These specific growth factors were not identified in this study. Mitogenic effects of epidermal growth factor on rat corticotropes have been reported by Childs et al. (14), albeit in a limited dose range. A paracrine or autocrine role for this growth factor in corticotrophic function has been postulated $(42,43)$. Pituitary adenoma cells have been reported to express membrane-anchored transforming growth factor- $\alpha$, indicating a role for it in pituitary tumorigenesis (44).

We have also shown that canine corticotrophic adenoma cells are less responsive to stimulation by CRH than are normal canine pituitary cells. These results confirm earlier reports on in vitro and in vivo studies (39, 45) that demonstrated a relative insensitivity of canine corticotrophic tumour cells to stimulation by CRH.

CRH-induced ACTH secretion from normal canine pituitary cells and from canine corticotrophic tumour cells was inhibited by glucocorticoids after 4 but not $24 \mathrm{~h}$ of incubation. The inhibition found after $4 \mathrm{~h}$ can be explained by the rapid inhibitory effect of glucocorticoids involving inhibition of the CRH-induced secretory process. To understand the observation that $\mathrm{CRH}-$ induced ACTH secretion could not be inhibited after $24 \mathrm{~h}$, two phenomena have to be considered. First, for human corticotrophic adenoma cells it has been reported that CRH is able to down-regulate glucocorticoid receptor mRNA, which may lead to a decreased response to glucocorticoids (46). Secondly, CRH-induced ACTH secretion has been reported to be rapidly desensitized in rat anterior pituitary cells when cultured in the absence of added glucocorticoids (47). The response of corticotrophic cells to CRH in vitro, cultured in the absence of glucocorticoids, would thus be relatively low compared with the in vivo situation in which background levels of glucocorticoids are present.

The impaired inhibition by glucocorticoids of the basal ACTH secretion of corticotrophic tumour cells during incubation with IGF-I seems to result from the 
lack of sensitivity of corticotrophic tumour cells to glucocorticoid inhibition, rather than to the ability of IGF-I to prevent glucocorticoid-provoked inhibition of ACTH secretion, as has been described for murine corticotrophic tumour cells (26).

In conclusion, the hypothalamic hormones $\mathrm{CRH}$ and AVP and the intrapituitary growth factor IGF-I do not have growth-stimulating effects on canine corticotrophic tumour cells. Canine corticotrophic tumours have an aberrant sensitivity to a growth-promoting factor present in FCS. This factor may have a profound role in the clonal expansion of these tumours and, in combination with the genetic alterations of the corticotrophic tumour cells, be responsible for the tumorigenesis of canine corticotrophic adenomas.

\section{Acknowledgements}

The authors would like to thank Adri Slob and Jeannette Wolfswinkel for their excellent technical support and Yvonne WEA Pollak and Joop Fama for preparing the figures. The critical reading of the manuscript by Dr BE Belshaw is greatly appreciated. This work was supported by NWO (Dutch Organization for Scientific Research) Grant 900-543-066.

\section{References}

1 Vallar L, Spada A \& Giannattasio G. Altered Gs and adenylate cyclase activity in human GH-secreting pituitary adenomas. Nature 1987330 566-568.

2 Landis CA, Masters SB, Spada A, Pace AM, Bourne HR \& Vallar L. GTPase inhibiting mutations activate the $\alpha$ chain of Gs and stimulate adenylyl cyclase in human pituitary tumours. Nature $1989340692-696$.

3 Tjordman K, Stern N, Ouknine G, Yossiphov Y, Razon N, Nordenskjold $\mathrm{M}$ et al. Activating mutations of the Gs $\alpha$-gene in nonfunctioning pituitary tumors. Journal of Clinical Endocrinology and Metabolism 199377 765-769.

4 Williamson EA, Harrison D, Ince PG, Kendall-Taylor P \& Harris PE. G-protein mutations in human pituitary adrenocorticotrophic hormone-secreting adenomas. European Journal of Clinical Investigation 199525 128-131.

5 Pei L, Prager D, Scheithauer B, Melmed S \& Herman V. Molecular characterization of pituitary tumours. Proceedings of the Third International Pituitary Congress. Endocrine Research and Education. 1993 pp 21-27.

6 Pei L, Melmed S, Scheithauer B, Kovacs K \& Prager D. H-ras mutations in human pituitary carcinoma metastases. Journal of Clinical Endocrinology and Metabolism 199478 842-846.

7 Karga HJ, Alexander JM, Hedley-White ET, Klibanski A \& Jameson JL. Ras mutations in human pituitary tumors. Journal of Clinical Endocrinology and Metabolism 199274 914-919.

8 Alvaro V, Levy L, Dubray C, Roche A, Peillon F, Querat B et al. Invasive human pituitary tumors express a point-mutated $\alpha$-protein kinase-C. Journal of Clinical Endocrinology and Metabolism 199377 1125-1129.

9 Herman V, Drazin NZ, Gonsky R \& Melmed S. Molecular screening of pituitary adenomas for gene mutations and rearrangements. Journal of Clinical Endocrinology and Metabolism 199377 50-55.

10 Cai WY, Alexander JM, Hedley-White ET, Scheithauer BW, Jameson JL, Zervas NT et al. Ras mutations in human prolactinomas and pituitary carcinomas. Journal of Clinical Endocrinology and Metabolism 199478 89-93.
11 Gertz BJ, Contreras LN, McComb DJ, Kovacs K, Tyrell JB \& Dallman MF. Chronic administration of corticotropin-releasing factor increases pituitary corticotroph number. Endocrinology $1987120381-388$.

12 McNicol AM, Kubba MAG \& McTeague E. The mitogenic effects of corticotrophin-releasing factor on the anterior pituitary gland of the rat. Journal of Endocrinology 1988118 237-241.

13 McNicol AM, Murray JE \& McMeekin W. Vasopressin stimulation of cell proliferation in the rat pituitary gland in vitro. Journal of Endocrinology $1990126255-259$.

14 Childs GV, Rougeau D \& Unabia G. Corticotropin-releasing hormone and epidermal growth factor: mitogens for anterior pituitary corticotropes. Endocrinology 1995136 1595-1602.

15 Asa SL, Kovacs K, Stefaneanu L, Horvath E, Billestrup N, Gonzalez-Manchon C et al. Pituitary mammosomatotroph adenomas develop in old mice transgenic for growth hormonereleasing hormone. Proceedings of the Society for Experimental Biology and Medicine 1990193 232-235.

16 Sakai T, Inoue K, Hasegawa Y \& Kurosumi K. Effect of passive immunization to gonadotropin-releasing hormone (GnRH) using $\mathrm{GnRH}$ antiserum on the mitotic activity of gonadotrophs in castrated male rats. Endocrinology 1988122 2803-2808.

17 Webster J, Ham J, Bevan JS \& Scanlon MF. Growth factors and pituitary tumors. Trends in Endocrinology and Metabolism 1989 1 95-98.

18 Halper J, Parnell PG, Carter BJ, Ren P \& Scheithauer BW. Presence of growth factors in human pituitary. Laboratory Investigation $199266639-645$.

19 Bach MA \& Bondy CA. Anatomy of the pituitary insulin-like growth factor system. Endocrinology $19921312588-2594$.

20 Kasselberg AG, Orth DN, Gray ME \& Stahlman MT. Immunocytochemical localization of human epidermal growth factor/ urogastrone in several human tissues. Journal of Histochemistry and Cytochemistry 198533 315-322.

21 Fisher DA \& Lakshmanan J. Metabolism and effects of epidermal growth factor and related growth factors in mammals. Endocrine Reviews $199011418-442$.

22 Baird A, Mormède P, Ying S, Wehrenberg WB, Ueno N, Ling N et al. A nonmitogenic pituitary function of fibroblast growth factor: regulation of thyrotropin and prolactin secretion. Proceedings of the National Academy of Sciences of the USA 198582 5545-5549.

23 Ferrara N, Schweigerer L, Neufeld G, Mitchell R \& Gospodarowicz D. Pituitary follicular cells produce basic fibroblast growth factor. Proceedings of the National Academy of Sciences of the USA 198784 5773-5777.

24 Gospodarowicz D, Ferrara N, Schweigerer L \& Neufeld G. Stuctural characterization and biological functions of fibroblast growth factor. Endocrine Reviews 1987 8 95-114.

25 Houben $\mathrm{H} \&$ Denef $C$. Bioactive peptides in anterior pituitary cells. Peptides 199415 547-582.

26 Van Wijk PA, Neck JW van, Rijnberk A, Croughs RJM \& Mol JA. Proliferation of the murine corticotropic tumour cell line AtT20 is affected by hypophysiotrophic hormones, growth factors and glucocorticoids. Molecular and Cellular Endocrinology 1995111 13-19.

27 Kemppainen RJ \& Peterson ME. Animal models of Cushing's disease. Trends in Endocrinology and Metabolism 19945 21-28.

28 Rijnberk A \& Mol JA. Adrenocortical function. In Clinical Biochemistry of Domestic Animals, pp 611-629. Ed JJ Kanekopp. San Diego: Academic Press 1989.

29 Van Wijk PA, Rijnberk A, Croughs RJM, Voorhout G, Sprang EPM \& Mol JA. Corticotropin-releasing hormone and adrenocorticotropic hormone concentrations in cerebrospinal fluid of dogs with pituitary-dependent hyperadrenocorticism. Endocrinology 1992 $1312659-2662$.

30 Voorhout G \& Rijnberk A. Cisternography combined with linear tomography for visualization of pituitary lesions in dogs with pituitary-dependent hyperadrenocorticism. Veterinary Radiology $19903174-78$.

31 Markowitz J, Archibald J \& Downie HG. Hypophysectomy in dogs. In Experimental Surgery, pp 630-643. Baltimore: The Williams \& Wilkins Co 1964. 
32 Van Zoelen EJJ, Oostwaard TMJ, van der Saag PT \& de Laat SW Phenotypic transformation of normal rat kidney cells in a growthfactor-defined-medium: induction by a neuroblastoma-derived transforming growth factor independently of the EGF receptor Journal of Cell Physiology 1985123 151-160.

33 Arts CJM, Koppeschaar HPE, Veeman W \& Thijssen JHH. A direct radioimmunoassay for the determination of adrenocorticotropic hormone (ACTH) and a clinical evaluation. Annals of Clinical Biochemistry 198522 247-256.

34 Thorner MO, Vance ML, Horvath E \& Kovacs K. The anterior pituitary. In Williams' Textbook of Endocrinology, pp 221-310. Eds JD Wilson \& DW Foster. Philadelphia: WB Saunders Company 1992.

35 Antoni FA. Hypothalamic control of adrenocorticotropin secretion: advances since the discovery of 41-residue corticotropinreleasing factor. Endocrine Reviews 19867 351-378.

36 Owens MJ \& Nemeroff CB. Physiology and pharmacology of corticotropin-releasing factor. Pharmacological Reviews 199143 425-473.

37 Orth DN. Corticotropin-releasing hormone in humans. Endocrine Reviews 199213 164-191.

38 Kling MA, Roy A, Doran AR, Calabrese JR, Rubinow DR, Whitfield $\mathrm{HJ}$ et al. Cerebrospinal fluid immunoreactive corticotropinreleasing hormone and adrenocorticotropin secretion in Cushing's disease and major depression: potential clinical implications. Journal of Clinical Endocrinology and Metabolism 199172 260-271.

39 Mol JA, Slob A, Middleton DJ \& Rijnberk A. Release of adrenocorticotropin, melanotropin and $\beta$-endorphin by pituitary tumors of dogs with pituitary-dependent hyperadrenocorticism. Frontiers in Hormone Research 198717 61-70.

40 Kolopp M, Poirel G, Vit P \& Perentes E. In situ analysis of adenohypophysis proliferative activity in beagle dogs. Pathology Research and Practice 1992188 663-667.
41 Tilemans D, Andries M \& Denef C. Luteinizing hormone-releasing hormone and neuropeptide $\mathrm{Y}$ influence deoxyribonucleic acid replication in three anterior pituitary cell types. Evidence for mediation by growth factors released from gonadotrophs. Endocrinology $1992130882-894$.

42 Fan X \& Childs G. Epidermal growth factor and transforming growth factor- $\alpha$ messenger ribonucleic acids and their receptors in the rat anterior pituitary: localization and regulation. Endocrinology $19951362284-2293$.

43 Fan X, Nagle GT, Collins TJ \& Childs G. Differential regulation of epidermal growth factor and transforming growth factor- $\alpha$ messenger ribonucleic acid in the rat anterior pituitary and hypothalamus induced by stress. Endocrinology $1995136873-$ 880 .

44 Ezzat S, Walpola IA, Ramyar L, Smyth HS \& Asa SL. Membraneanchored expression of transforming growth factor- $\alpha$ in human pituitary adenoma cells. Journal of Clinical Endocrinology and Metabolism 199580 534-539.

45 Van Wijk PA, Rijnberk A, Croughs RJM, Wolfswinkel J, Selman P \& Mol JA. Responsiveness to corticotropin-releasing hormone and vasopressin in canine Cushing's syndrome. European Journal of Endocrinology $1994130410-416$.

46 Sheppard KE, Roberts JL \& Blum M. Adrenocorticotropinreleasing factor down-regulates glucocorticoid receptor expression in mouse corticotrope tumor cells via an adenylate cyclasedependent mechanism. Endocrinology $1991129663-670$.

47 Ceda GP \& Hoffman AR. Glucocorticoid modulation of corticotropinreleasing factor desensitization in cultured rat anterior pituitary cells. Endocrinology 1986118 58-62.

Received 27 March 1997

Accepted 20 October 1997 